\title{
DIMENSI SOSIAL PADA SISI KEBUTUHAN (DEMAND SIDE) BAGI PERAWATAN IBU DAN ANAK
}

\author{
Ni Komang Yuni Rahyani \\ Jurusan Kebidanan Poltekkes Kemenkes Denpasar \\ yunirahyani@yahoo.co.id
}

\begin{abstract}
Midwifery care must be given in accordance with the needs of mothers as users of health services, and the demand side are based on a variety of factors, namely the availability of quality service and comprehensive and competent personnel. The purpose of writing this article is to give an overview of the factors as a social determinant of fulfillment of health services for mothers and newborns from demand side. The availability of, access to and improvement of maternity services was a major problem, especially in developing countries and in poor countries. Determinants of demand-side as factors that affect the needs at the level of individuals, households and communities. Care or midwifery care in accordance with the standards, especially meet maternal health care coverage as a key priority at this time must meet availability, affordability and effectiveness of services .
\end{abstract}

Keywords: demand-side, midwifery care, accessibility, effectiveness

\begin{abstract}
Abstrak: Asuhan kebidanan harus diberikan sesuai dengan kebutuhan ibu sebagai pengguna pelayanan kesehatan, dan sisi kebutuhan (demand side) tersebut didasari oleh berbagai faktor, yaitu ketersediaan pelayanan yang berkualitas dan komprehensif serta tenaga yang kompeten. Tujuan penulisan artikel ini adalah untuk memberi gambaran mengenai faktor-faktor sebagai determinan sosial dari pemenuhan pelayanan kesehatan ibu dan bayi baru lahir yang dari sisi demand. Faktor ketersediaan, akses dan peningkatan pelayanan maternitas masih menjadi kendala besar terutama di negara berkembang dan di negara miskin. Determinan sisi kebutuhan (demand-side) sebagai faktor yang mempengaruhi kebutuhan pada level individual, rumah tangga dan komunitas. Pelayanan atau asuhan kebidanan yang sesuai dengan standar, terutama memenuhi cakupan pelayanan kesehatan ibu sebagai prioritas kunci saat ini harus memenuhi ketersediaan pelayanan, keterjangkauan dan keefektifan pelayanan.
\end{abstract}

Kata kunci: sisi kebutuhan, asuhan kebidanan, aksesibilitas, efektivitas 


\section{Pendahuluan}

Intervensi atau tindakan dari sisi kebutuhan ibu (maternal) adalah sangat dibutuhkan untuk meningkatkan penggunaan pelayanan kesehatan maternal. Faktor utama yang secara langsung mempengaruhi sisi kebutuhan (demand side) adalah: pengetahuan mengenai tanda bahaya pada masa kehamilan dan kelahiran bayi, pembiayaan, geografis, dan akses sosial untuk perawatan kesehatan, kualitas pelayanan serta norma berbasis gender maupun nilainilai seputar perilaku mencari pelayanan kesehatan maternal.

Terdapat tiga konsep kunci yang berkaitan dengan kebutuhan untuk perawatan selama masa kehamilan dan kelahiran bayi, di antaranya: 1) ketersediaan pengetahuan yang sensitif budaya secara kontekstual, 2) upaya sistem kesehatan mengatasi hambatan sosial untuk meningkatkan pelayanan, serta 3) mengatasi kendalakendala berbasis gender ${ }^{1}$.

Kesehatan ibu, bayi baru lahir, dan anak mengingatkan satu masalah signifikan di negara-negara berkembang, setiap tahun sebanyak 358.000 orang perempuan meninggal selama kehamilan dan kelahiran bayi dan diestimasikan sebanyak 7,6 juta anak meninggal pada usia di bawah lima tahun (balita). Mayoritas kematian ibu terjadi selama atau segera setelah kelahiran bayi,yang disebabkan oleh penyebab medis terutama perdarahan, tekanan darah tinggi, persalinan memanjang dan obstruksi, infeksi maupun aborsi yang tidak aman ${ }^{2}$.

Risiko tertinggi kematian pada anak adalah dalam 28 hari kehidupan yaitu sebanyak $40 \%$ dari jumlah kematian balita atau sejumlah tiga juta kematian. Lebih dari 1,5 kematian bayi baru lahir terjadi dalam 24 jam pertama kehidupan dan $75 \%$ terjadi dalam satu minggu pertama yang disebabkan oleh : kelahiran prematur, infeksi yang berat dan aspiksia. Perlu dipahami, bahwa anak-anak yang hidup di negara miskin memiliki angka kematian 18 kali lebih tinggi meninggal sebelum berusia lima tahun jika dibandingkan dengan anakanak di negara-negara kaya ${ }^{2}$.

Kesehatan ibu dan nutrisi yang baik adalah berkontribusi bagi kelangsungan hidup anak. Intervensi- 
intervensi yang esensial belum dilakukan untuk mengatasi kondisi-kondisi kesehatan lainnya yang berkaitan dengan kesakitan dan kematian neonatus. Berbagai intervensi dan strategi untuk meningkatkan kesehatan maupun kelangsungan hidup ibu, bayi baru lahir dan anak sangat erat berkaitan dan harus disiapkan melalui pendekatan perawatan yang berkesinambungan (continuum of care). ${ }^{3}$

Strategi utama yang dilakukan adalah upaya kolaborasi difokuskan pada intervensi klinis yang kritis yang digambarkan pada tenaga ahli di klinik obstetric/ginekologi, bidan dan kesehatan bayi baru lahir. Untuk meningkatkan akses menuju tenaga terlatih yang menggunakan kerangka perawatan ibu, bisa menggunakan intervensi berbasis evidence, yang mencakup: 1) perawatan antenatal terfokus, 2) meningkatkan kapasitas keterampilan provider (dokter, bidan dan perawat) untuk menyediakan pelayanan obstetri dan neonatus dasar (PONED), 3) meningkatkan akses dan penggunaan pelayanan kegawatdaruratan obstetric dan bayi baru lahir di tingkat dasar dan komprehensif, 4) menyediakan informasi keluarga berencana dan pelayanan selama antenatal periode postpartum, 5) meningkatkan akses dan penggunaan layanan perawatan pasca aborsi yang berkualitas untuk mencegah kematian perempuan akibat komplikasi aborsi, dan 6) meningkatkan upaya pencegahan infeksi yang berkualitas untuk menurunkan infeksi pascapartum dan bayi baru lahir ${ }^{3}$.

Terdapat berbagai komponen yang mempengaruhi kebutuhan bagi pelayanan kesehatan ibu dan bayi baru lahir, di antaranya: tersedia pelayanan yang berkualitas dan komprehensif serta tenaga yang kompeten. Intervensi yang diberikan untuk menurunkan kesakitan dan kematian ibu serta bayi baru lahir adalah berbasis evidence yang terbaik.

Penulisan artikel ini bertujuan untuk memberi gambaran mengenai faktor-faktor sebagai determinan sosial dari pemenuhan pelayanan kesehatan ibu dan bayi baru lahir yang dari sisi demand. Secara khusus tujuannya: 1) memberi informasi mengenai determinan sosial pelayanan kesehatan ibu dan bayi baru lahir untuk 
menurunkan angka kesakitan dan kematian ibu dan bayi baru lahir, 2) menguraikan perencanaan dan implementasi paket intervensi kesehatan ibu dan bayi baru lahir sesuai evidence terbaik.

\section{Pembahasan}

Faktor ketersediaan atau availabilitas, akses dan peningkatan pelayanan maternitas masih menjadi kendala besar terutama di negara berkembang dan di negara miskin. Data yang diperoleh berdasarkan bukti terkini di berbagai negara, diperoleh bahwa terjadi berjuta kematian pada perempuan, bayi baru lahir dan anak yang sebenarnya kematian tersebut dapat dicegah. Di sisi lain, berbagai intervensi telah diupayakan untuk menyelamatkan kehidupan perempuan dan anak, namun pelayanan yang dibutuhkan tidak tersedia. Data statistik di seluruh dunia menunjukkan jika setiap tahun telah terjadi : 1) lebih dari 60 juta perempuan melahirkan di rumah tanpa ditolong oleh tenaga terlatih $^{4}$; 2) sekitar 530.000 perempuan meninggal akibat komplikasikomplikasi kehamilan, dengan 68.000 dari kematian tersebut disebabkan oleh aborsi yang tidak aman ${ }^{5}$; 3) sekitar 4 juta bayi meninggal dalam satu bulan pertama kehidupannya atau pada periode bayi baru lahir), dan lebih dari 3 juta kematian bayi lahir mati atau stillbirth ${ }^{6}$; 4) lebih dari 10 juta kematian anak usia kurang dari lima tahun $^{7}$; 5) selanjutnya, hampir semua (99\%) kematian ibu, bayi baru lahir dan anak terjadi di negara-negara miskin dan berkembang.

Kesehatan ibu, bayi baru lahir, dan anak atau Maternal, Newborn, Child Health (MNCH) menjadi isu utama di berbagai belahan dunia, dan program yang dilakukan adalah perawatan yang berkesinambungan atau continuum of care. Upaya perawatan ini mengalami hambatan atau kendala baik di lingkungan komunitas maupun di fasilitas pelayanan kesehatan ${ }^{8}$.

Konsep dari continuum of care adalah kesehatan dan kesejahteraan perempuan, bayi baru lahir, dan anak yang berkaitan lebih dekat dan dikelola sebagai satu kesatuan. Model ini disebut dengan ketersediaan (availability) dan akses untuk 
kesehatan esensial dan pelayanan reproduksi.

Upaya continuum of care dibarengi dengan pelayanan bagi ibu dan neonatal yang terstandar untuk membantu pengelola program dan penyedia layanan kesehatan (provider), untuk: a) mengembangkan standar perawatan kesehatan ibu dan neonatal berbasis bukti nasional maupun subnasional, b) mengenalkan setting standar dan meningkatkan kualitas proses di level fasilitas seperti meningkatkan akses dan kualitas dari pelayanan kesehatan ibu dan neonatal, c) menyediakan pelayanan kesehatan yang efekif bagi ibu dan neonatal, d) menggunakan sumber daya yang tersedia untuk mencapai outcome kesehatan yang optimal, dan e) memperbaiki kepuasan individual, keluarga dan komunitas serta pemanfaatan pelayanan kesehatan ibu dan neonatal ${ }^{9}$.

Tantangan dari para pengambil kebijakan dan program kesehatan reproduksi untuk meningkatkan pencapaian dari Millenium Development Goals (MDG's) adalah mencakup beberapa hal, di antaranya : akses dan kualitas dari keluarga berencana dan pelayanan kesehatan reproduksi dan seksual yang masih rendah, pertolongan persalinan oleh tenaga terlatih dan sistem rujukan yang rendah, tingginya angka aborsi yang tidak aman dan rendahnya kualitas layanan pascaaborsi, layanan kesehatan reproduksi termasuk informasi yang terbatas dan tidak memenuhi kebutuhan remaja, serta belum ada integrasi upaya pencegahan dan penanganan dari infeksi saluran reroduksi termasuk HIV/AIDS, dengan pelayanan kesehatan reproduksi dan seksual lainnya ${ }^{10}$.

Pada Gambar di bawah, dipaparkan paket pelayanan kesehatan reproduksi dan seksual menurut Williams, Warren, \& Askew (2010), mencakup dua hal pokok yaitu: pelayanan keluarga berencana dan infeksi saluran reproduksi. Pelayanan lainnya adalah layanan: antenatal, HIV/AIDS, kesehatan ibu dan bayi baru lahir (newborn), dan pasca aborsi/pascasalin. ${ }^{11}$ 

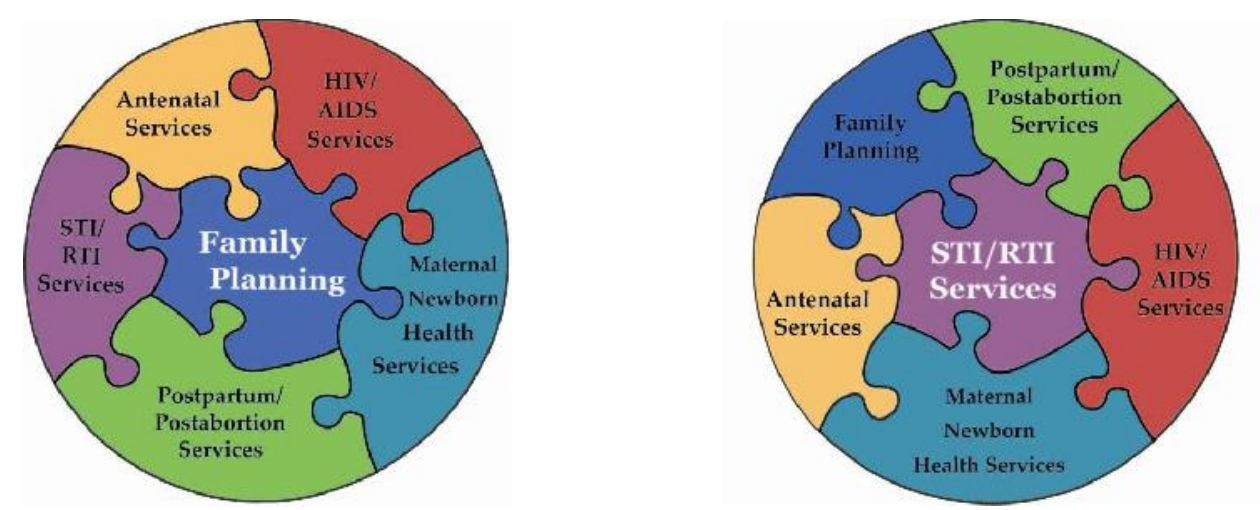

Gambar 1. Paket layanan kesehatan reproduksi dan seksual sepanjang siklus hidup ${ }^{11}$.

Menurut JHPIEGO (Organisasi kesehatan internasional nirlaba yang berafiliasi dengan The John Hopkins University), upaya perawatan yang berkesinambungan (continuum of care) merupakan strategi berbasis bukti yang efektif meningkatkan derajad kesehatan ibu dan bayi baru lahir, karena difokuskan kepada determinan utama kesehatan ibu dan anak. Beberapa strategi tersebut, adalah: 1) pelayanan antenatal terfokus, sebuah platform bagi integrasi perawatan yang luas untuk meningkatkan outcome ibu dan bayi baru lahir, termasuk pencegahan dan penatalaksanaan malaria dalam kehamilan serta pencegahan penularan HIV dari ibu ke anak (PPIA); 2) meningkatkan kapasitas dari provider terlatih (dokter, bidan,perawat) untuk menyediakan perawatan obstetric dan bayi baru lahir (newborn) dasar untuk mendukung persalinan normal dan kelahiran termasuk kehadiran pendamping, makanan dan cairan, dan memilih posisi saat persalinan dan kelahiran; 3) meningkatkan akses dan penggunaan untuk perawatan emergensi dasar dan komprehensif obstetrik dan bayi baru lahir, membantu memastikan bahwa hampir $15 \%$ dari kelahiran yang berkembang ke arah komplikasi yang didentifikasi dan ditangani secara tepat. Hal ini termasuk identifikasi dan manajemen preeklamsia dan ekalmsia, pencegahan dan penatalaksanaan dari persalinan macet (satu penyebab terbesar dari fistula obstetrik), perdarahan pascasalin dan asfiksia bayi baru lahir, sebagai 
penyebab umum kesakitan dan kematian ibu dan bayi baru lahir; 4) Pandangan mengenai informasi dan pelayanan keluarga berencana, selama periode antenatal dan pascasalin, intervensi menyelamatkan hidup lainnya yang mungkin bisa tercapai lebih dari $90 \%$ dari perempuan usia reproduksi di daerah dengan angka kelahiran yang tinggi; 5) meningkatkan akses dan penggunaan menuju perawatan pascaaborsi yang berkualitas untuk mencegah kematian dari komplikasi aborsi; 6) meningkatkan kualitas pelayanan dan praktik pencegahan infeksi yang membantu menurunkan infeksi pascasalin dan bayi baru lahir ${ }^{3}$.

Inti dari upaya di atas adalah ketersediaan dari sumber daya manusia/ provider yang terlatih serta sarana yang terjangkau dari segi jarak maupun biaya. Kompetensi provider menjadi sorotan penting untuk menurunkan komplikasi maupun dampak negatif dari perawatan yang diberikan. Di sisi lain, terdapat hambatan lain dari sisi budaya bagi peningkatan status kesehatan ibu dan bayi baru lahir, yaitu norma dan nilai gender. Ditinjau dari kerangka kerja ekonomi bagi utilisasi perawatan kesehatan, diketahui terdapat determinan sisi kebutuhan (demandside) sebagai faktor yang mempengaruhi kebutuhan pada level individual, rumah tangga dan komunitas ${ }^{12}$.

Model ini menjelaskan mengenai hambatan untuk menjangkau fasilitas kesehatan dan keterlambatan memperoleh perawatan yang tepat ketika perempuan mencapai fasilitas pelayanan. Keterlambatan pertama terjadi ketika perempuan dan keluarganya terlambat mengenal gejala dan tanda bahaya (danger signs) dalam kehamilan dan kelahiran bayi. Keterlambatan kedua adalah mencapai fasilitas kesehatan, yang umumnya disebabkan oleh hambatan biaya, hambatan geografis

\section{Simpulan dan Saran}

Keberhasilan asuhan bagi ibu dan bayi baru lahir dipengaruhi secara langsung oleh faktor ketersediaan sarana dan prasarana (personel kesehatan, infrastrukstur fisik, obatobatan, peralatan, transportasi dan sistem komunikasi). Asuhan kebidanan 
berupa pelayanan obstetric neonatal emergensi dasar (PONED) dan pelayanan obstetric neonatal emergensi komprehensif (PONEK) membutuhkan ketersediaan sumber daya manusia dan sarana prasarana pendukung yang memadai.

Ruang lingkup kewenangan bidan juga diperluas untuk memberikan semua pelayanan PONED ditambah resusitasi bayi baru lahir. Pemenuhan kebutuhan pelayanan obstetrik dan neonatal yang tepat dapat menurunkan keterlambatan di dalam mengenali masalah, terlambat merujuk ke fasilitas rujukan dan terlambat mendapat penanganan yang tepat di fasilitas kesehatan rujukan.

Peran dari sektor pemerintah terutama pembuat kebijakan kesehatan untuk memenuhi sarana prasarana kesehatan termasuk infrastrukstur yang memadai, ditunjang dengan peran serta individu (ibu), keluarga dan masyarakat untuk meningkatkan kesehatan berpengaruh besar untuk menurunkan angka kesakitan dan kematian ibu dan bayi. Pelayanan atau asuhan kebidanan yang sesuai dengan standar, terutama memenuhi cakupan pelayanan kesehatan ibu sebagai prioritas kunci saat ini harus memenuhi ketersediaan pelayanan, keterjangkauan dan keefektifan pelayanan.

\section{Daftar Pustaka}

1. Mumtaz, Z and Levay, A. 2012. Demand for maternity care: beliefs, behaviour and social access. (In Hussein, J,.Mc CawBinns,A. and Webber,R (eds). Maternal and Perinatal Health in Developing Countries). CAB International, London, UK. 2012.

2. The Partnership for Maternal, Newborn \& Child Health. 2011. A Global Review of the Key Interventions Related to Reproductive, Maternal, Newborn and Child Health (Rmnch). Geneva, Switzerland: PMNCH

3. JHPIEGO. 2016. Maternal, Newborn and Child Health. http://www.jhpiego.org/content/mat ernal-newborn-and-child-health. Di unduh pada tanggal 15 Februari 2016.

4. Rudolf Knippenberg et al., "Systematic Scaling Up of Neonatal Care in Countries," The Lancet Neonatal Survival Series, No. 3 (March 2005).

5. World Health Organization (WHO), The World Health Report 2005: Make Every Mother and Child Count (Geneva: WHO, 2005).

6. WHO, The World Health Report 2005: Make Every Mother and Child Count; and Jelka Zupan and Elizabeth Aahman, Perinatal Mortality for the Year 2000: 
Estimates Developed by $\mathrm{WHO}$ (Geneva: WHO, 2005).

7. Robert Black, Saul Morris, and Jennifer Bryce, "Where and Why Are 10 Million Children Dying Every Year?" The Lancet 361, no. 9376 (2003): 2226-34.

8. Susan Otchere, Mary Beth Powers, and Elizabeth Ransom, "The Household to Hospital Continuum of Care Approach for Maternal and Newborn Care," Journal of Health, Population, and Nutrition 24, no. 2 (forthcoming June 2006); and WHO, The World Health Report 2005: Make Every Mother and Child Count.

9. World Health Organization (WHO), Integrated management of pregnancy and childbirth. Standards for maternal and neonatal care. Department of Making Pregnancy Safer. (WHO, 2007).

10. World Health Organization (WHO), The WHO Strategic Approach to strengthening sexual and reproductive health policies and programmes. WHO: Geneva (2007).

11. Williams, K., Warren, C., and Askew, I. Planning and Implementing an Essential Package of Sexual and Reproductive Health Services Guidance for Integrating Family Planning and STI/RTI with other Reproductive Health and Primary Health Services. (2010). UNFPA \& Population Council.

12. Ensor,T and Cooper, S. Overcoming barriers to health service access: Influencing the demand side. Health Policy and Planning. (2004). 19 (2), 69-79 